\title{
Sovereignty, Legitimacy and Fundamental Rights as Limitations to Criminalisation Power of the State
}

Simeneh Kiros Assefa *

\begin{abstract}
Sovereignty is a doctrine of power that constitutes and vests supreme political power in the state, including criminal lawmaking power. However, this supreme power of exercising coercive state power through the criminal law is not unlimited. Because the justifications for sovereignty are also justifications for criminal lawmaking power of the state, they are discussed together. After presenting the justification and legitimacy of sovereignty and the criminal lawmaking power of the sovereign, this article discusses criminalization power of the state in three parts: the limitation inherent in the notion of sovereignty, in constitutionalism and the bill of rights. Finally, it reviews the practice of criminalisation in Ethiopia.
\end{abstract}

\section{Key terms}

Sovereignty · Criminalization · Legitimacy · Principle theory $\cdot$ Legislative rationality $\cdot$ Coordination theory

DOI http://dx.doi.org/10.4314/mlr.v12i1.5

Received: 8 April 2018

Accepted: 30 September 2018

This article is licensed under a Creative Commons Attribution-NonCommercial-

NoDerivs (CC BY-NC-ND)

\section{Introduction}

The state is the highest form of socio-political organisation. Sovereignty is another political devise in this organisation, and some even contend that it is one form of organisation. Intuitively understood, sovereignty is the supreme power of the state. However, sovereignty is a social construct meant to represent the legitimate power exercised by the state, not the naked power. Stated directly, sovereignty is an instrumental concept justifying the power exercised by the

* Simeneh Kiros Assefa: LL.B (Addis Ababa University), LL.M (University of Pretoria), LL.M (Kyushu University), LL.M (University of San Francisco); Assistant Professor of Law at AAU Law School, Attorney-at-Law and member of California State Bar (inactive).Email: simeneh@ simenehlaw.com 
state; and embedded in the doctrine of sovereignty is legitimacy. Legitimacy refers to not only the power that is exercised by the state, but also the very creation of the state itself. Authorities have endeavoured to establish the foundational legitimacy of the state.

The exercise of coercive power by the state is justified by the doctrine of sovereignty. One such coercive power is criminalisation, declaring conducts criminal and attaching punishments for violation of such norms whether it is fine, imprisonment or death. However, such power is not unlimited. It is limited in the doctrine of sovereignty itself; it is also limited by the law. The exercise of sovereign power and its legitimacy is justified in and by a constitution. As the very notion of a constitution is associated with limited government, the criminalising power of the government is limited in the constitution.

Such limitation takes both structural and substantive forms. The structural form is accomplished in two ways: the first is the institutional structure in the form of separation of power among the three branches of the government relating to their respective jurisdiction, and the second is the normative structure. The substantive limitation on the power of the government is incorporated in the form of the bill of rights and other constitutional principles that guide the legislature and the body conducting constitutional litigation.

The bill of rights puts restriction on the legislative power through both the adjudicative and legislative processes. In the adjudication process, fundamental rights are treated as principles. Principles are optimisation commands to be realised to the maximum as facts and norms permit; where there is a collision between the various principles, the conflict is to be resolved through a weighing process; fundamental rights are principles that necessarily are taken into consideration. However, those constitutional norms also include principles which may be called normative judgments that require balancing in case of conflict of values. Democracy requires that every relevant conflicting interest be taken into consideration and all contradictory choices are decided by majority. The weighing of those conflicting values is governed by the principle of proportionality.

This article enquires into whether the sovereign power of criminalisation of the state is unlimited. Section 1 attempts to describe the notion of sovereignty as a politico-legal technique in the social organisation, the state. It discusses the scope and source of sovereignty. It depicts the concept as a social construct and as an instrument of 'the powerful' in the social structure, along with restrictions to such power inherent in the doctrine itself. Section 2 deals with the notion of legitimacy in the framework of sovereignty. As it is logically difficult to establish foundational legitimacy of the state or sovereignty, the alternative approach is moving the argument to the second level legitimacy, legitimacy of state action, including legislation as a method of limiting criminalisation. 
The notions of sovereignty and legitimacy are discussed in the context of a constitution. Section 3 therefore deals with constitution and constitutionalism incorporating both structural and substantive limitations to the power of the state. Legitimacy is about the exercise of sovereign authority. Section 4 discusses criminalisation, doctrinal and structural limitations to criminalisation inherent in the criminal law itself. The substantive limitations to the power of the state are fundamental rights. The substantive limitations of the coercive power of the state both in the context of adjudication as well as legislation are discussed in section 5. Section 6 illustrates the justification and practice of criminalisation in Ethiopia.

\section{The Doctrine of Sovereignty: Overview}

The state is the modern politico-social structure invented by society; and sovereignty is an aspect of such modern state. For Kriegel, it is a "doctrine of power;" it "is the form that gives being to the state; it is inseparable from the state; without it, the sate vanishes". ${ }^{1}$ Although the doctrine of state sovereignty dominates our legal and political theory and practice, there is little agreement regarding the description of the nature of the legal-political doctrine. Sovereignty, holds Lutz, "is a constitutional order that marries justice with power in such a way as to tame that power and turn it to the service of civil society". ${ }^{2}$

Likewise, Kriegel considered sovereignty as "the state under the rule of law;" as a "legitimate, rational and responsible exercise of power". ${ }^{3}$ The state, in her opinion, is "a legal, institutional and moral construct" that cannot be reduced into "economic or social interests" as was done by Marx and his followers. ${ }^{4}$ Nor can the state "be identified with despotism" as some governments would like to. ${ }^{5}$ Coming after the collapse of feudalism, Kriegel describes sovereignty as

\footnotetext{
${ }^{1}$ B Kriegel (1989), The State and the Rule of Law (Marc A. LePain and Jeffrey C. Cohen Translation, 1995.) at 15. [citations omitted.]

${ }^{2}$ DS Lutz (2006), Principles of Constitutional Design (Cambridge University Press) at 26.

${ }^{3}$ Kriegel, supra note 1 , at 17 .

${ }^{4}$ Id., at 27. For instance, Marx and his followers argue that the state which operates as an instrument of oppression would wither away .

${ }^{5}$ Blandine Kriegel's argument is that despotism is not sovereignty. She contends that "the classical state did not function in ways that a despotic state did. The former did not control its intellectuals nor transform them into mercenaries. [...] it established research institutions, thereby running the enormous risks of critique and opposition, and subjecting its power, de facto, to law." Id., at 7. Often, the classical writers were critical of the government of their time. Their greatest challenge had come from the church, not from the state. When they display such extra-ordinary intellectual quality, they would be appointed to high offices or would be given great responsibilities. However, Kriegel also argues that
} 
"peace," not naked power. ${ }^{6}$ There are also those who see sovereignty otherwise. For instance, Pusterla asserts that the notion of sovereignty is "an organised hypocrisy" "because the existence of sovereignty is taken as evident simply for a lack of evidence, as "a simple act of faith", or "a belief in a fiction". 8

We cannot define the notion of sovereignty as though it is physically 'out there'; nor can we fully explain the relation between sovereignty and power; but we can only describe how it operates within the framework of the notion of state and how it is skilfully used by those in power. There is a general agreement that sovereignty is a social construct and some may argue that it is a delegated power. ${ }^{9}$ The designation of the word and the referent are always subjects of debate as the content, scope and source of sovereignty is constantly evolving. There appears to be a general consensus that the doctrine of sovereignty is an instrumental concept that institutionalises the 'ultimate' or 'supreme political power' in an entity, such as, the modern state. ${ }^{10}$ The statist notion of sovereignty is paradigmatically thought in the context of the state ${ }^{11}$ that sovereignty and state mutually explain each other. ${ }^{12}$

\subsection{The state and sovereignty}

Sovereignty is having and exercising "supreme political power" domestically without external interference. ${ }^{13}$ The doctrine of sovereignty is almost exclusively manifested in the exercise of authority by such entity as the state to the extent

the doctrine of sovereignty is 'opening the door' to despotism, because there is a "slippery slope from the sovereign state to the totalitarian state." Id., at 16.

${ }^{6}$ Id., at 18, 21-24. Sovereignty is antithesis of feudalism in that "it was not based on military power, and it was not a dominium, because it did not institute a relation of subjugation. ...the sovereign is not a creature of war but rather of peace, and that it prefers pacific negotiation of rights to the clamour of arms." Id., at 21.

${ }^{7}$ ERG Pusterla (2016), The Credibility of Sovereignty - The Political Fiction of a Concept (Springer) at 2, 10 .

${ }^{8}$ Id., at $5,9,31$.

${ }^{9}$ Lutz also states that "constitutionalism has emerged as the best technology, the best human invention for organizing society. ... Sovereignty is itself a part of political technology that has come to be known as constitutionalism." Lutz, supra note 2, at 27. He argues that such creation of the notion of sovereignty is guided by two brute facts - the human desire to survive in liberty and freedom, and the need for human institutions. Id., at 28-30. Also, see his discussion on 'popular sovereignty', at 73. Likewise, Biersteker and Weber contend that sovereignty is "an inherently social concept." [emphasis in the original]. It is "socially constructed, as in the modern state system." TJ Biersteker and C Weber (1996), "The Social Construction of State Sovereignty" in TJ Bierstekerand C Weber (eds), State Sovereignty as Social Construct (Cambridge University Press) at 1, 3, $11 \mathrm{ff}$.

${ }^{10}$ Lutz, supra note 2, at 32, 34 .

${ }^{11}$ Id., at 31, 35.

${ }^{12}$ Kriegel, supra note 1 , at 15.

${ }^{13}$ Lutz, supra note 2, at 27. 
we could not see a distinction between law and violence. ${ }^{14}$ Such monopoly of the coercive power of the state is manifested in tax law, criminal law and conscription. ${ }^{15}$ It is also the power to sanction private relationships, such as, recognition of marriage and enforcement of contracts. In the exercise of such sovereign and exclusive coercive power, the state has the authority to make laws and establish institutions to enforce them.

Often, the elements of state are also discussed as elements of the doctrine of sovereignty that there does not seem to be distinction between the notions of state and sovereignty because they are inextricably linked. ${ }^{16}$ For instance, a state may be recognised as sovereign when it has a territory, and population on which a certain group claiming recognition also exercises effective control authority. ${ }^{17}$ The fine distinction made by Biersteker and Weber is that the state is 'an identity' while sovereignty is 'an institution' 18 that sovereignty "links ... the state to practice". 19

\subsection{Justifications for sovereignty}

Society organises itself for a better protection of its interests, whatever the content of such interests may be. ${ }^{20}$ It is often argued that, such organisation whether it is under a strongman or a modern politico-social structure, such as,

${ }^{14}$ Lutz argues that the reason why sovereignty is the preferred descriptor of the notion of supreme power is that it "implies the minimal use of force and violence and, thereby minimal injustice." Lutz, supra note 2, at 32. Pusterla, on the other hand, states that it is "the point of indistinction between violence and law, the threshold on which violence passes over into law and law passes over into violence." [citations omitted] Pusterla, supra note 7 , at 1 .

${ }^{15}$ BM Leiser (2008), "On Coercion" in DA Reidy and WJ Riker (eds), Coercion and the State (Springer) at 37.

${ }^{16}$ Biersteker and Weber, supra note 9 , at 8,11 .

${ }^{17}$ Id., at 2, 11. Kriegel, supra note 1, at 29-31.

${ }^{18}$ Biersteker and Weber, supra note 9, at 11.

${ }^{19}$ Id., at 12 . Wintgens referred to sovereignty as 'black box' to describe the indispensable nature of sovereignty as a source of power as well as the confusion surrounding it. LJ Wintgens (2007), "Legitimacy and Legitimation from the Legisprudential Perspective" in LJ Wintgens (ed), Legislation in Context: Essays in Legisprudence(Ashgate Publishing at 30 ff.; LJ Wintgens, (2012), Legisprudence: Practical Reason in Legislation (Ashgate Publishing) at $212-214$.

${ }^{20}$ In classical writings, the two rights, sometimes called natural rights, that were said to be in want of protection were property rights and liberty (personal security). See, for instance, Kriegel, supra note 1, at 21-25. J Dunn (2013), "Legitimacy and Democracy in the World Today" in J Tankebe and A Liebling (eds), Legitimacy and Criminal Justice: An International Exploration (Oxford University Press) at 11, 12. 
the state, it is meant to promote the 'common good' of its members. ${ }^{21}$ One such theory of the justification and legitimation of the creation of the state is the social contract theory which had been the secular source of justification for the existence of the state. ${ }^{22}$ However, in several recent critiques, the social contract theory is challenged for the lack of actual and unanimous consent. ${ }^{23}$ This challenge is both on the procedure and the substance of the theory. ${ }^{24}$

Barnett argues that there is no actual and unanimous consent in the social contract; nor would the opportunity to vote, residence, or acquiescence constitute or substitute consent. ${ }^{25}$ Therefore, in search of other justifications, the circumstances that were said to exist at a particular moment in history could be explained by a 'coordination theory'. ${ }^{26}$ This theory upholds that the foundation of the constitution is not our consent, which is a positive assent; it is rather acquiescence to the existing convention for lack of effective coordination of opposition to the constitution. ${ }^{27}$ In this theory, the minority's interests are better protected under the existing constitutional framework because it is so costly to organise an opposition. ${ }^{28}$

As is always the case, the theories were developed as an ex post facto justification for power. Thus, the source of sovereignty appears to have failed the foundational legitimacy. Hume holds that almost "all the governments which exist [...]have been founded originally either upon usurpation or conquest, or

${ }^{21}$ A Bhagwat (2010), The Myth of Rights: The Purposes and Limits of Constitutional Rights (Oxford University Press) at 48; Lutz, supra note 2, at 23, 24. This notion of 'common good' pushed Beccaria to develop the doctrine which later is named by Bentham to be utilitarianism, "the greatest happiness shared among the greater number." C Beccaria, On Crimes and Punishments and Other Writings (R Bellamy ed, 1995) at 7. P Riley (1982), Will and Political Legitimacy: A Critical Exposition of Social Contract Theory in Hobbes, Locke, Rousseau, Kant, and Hegel, Harvard University Press, at 3, 5.

${ }^{22}$ Beccaria opines that the social contract theory is not only the justification for the existence of the state but also for the use of coercive state power. He argued that "the foundation of the sovereign's right to punish crimes [is] the necessity of defending the repository of the public well-being from the usurpations of individuals" which "compelled them to give up a part of their freedom." Beccaria, supra note 21, at 7, 9, 11.

${ }^{23}$ RE Barnett (2003), “Constitutional Legitimacy”, 103 Colum L Rev 111, at 115-118.

${ }^{24}$ Procedurally, unanimity of consent is an impossible condition; substantively, there may, at least, be one person that would oppose the proposition. In fact, Hardin thoroughly discusses why the social contract theory actually is not a contract as we properly understand it. R Hardin "Constitutionalism" in B Weingast and DA Wittman (eds), 2006, The Oxford Handbook of Political Economy, Oxford University Press, at 291-293.

${ }^{25}$ Barnett, supra note 23, at 115-127.

${ }^{26}$ Hardin, supra note 24, at 297. Wintgens examined it as part of a trading-off in the legitimation process of sovereignty. Wintgens (2012), supra note 19, at $231 \mathrm{ff}$.

${ }^{27}$ Ibid.

${ }^{28}$ Id., at 298. 
both, without any pretence of a fair consent or voluntary subjection of the people". ${ }^{29}$ Thus, aligned with Kant's hypothetical consent, Rawls established his principles of justice for the establishment of a "well-ordered and just society" in which the coercive intervention of the state is justified. ${ }^{30}$ His is not about the foundational legitimacy of the constitution; it is rather a subsequent legitimation of state conduct based on the principles of equality of opportunity. ${ }^{31}$

In his theory of law and state, Kelsen, on the other hand, argues that, law and power are two sides of a coin; and one cannot exist without the other ${ }^{32}$ The primary rule is authorising certain conduct and the secondary rule is providing for a sanction for its violation. The law gets its validity from its superior law. But at the top is the constitution as a grundnorm, the only presupposition. ${ }^{33}$ Following his argument, the 'social contract' is the justification for sovereignty. In this notion of sovereignty, the supreme power is that of the state not a particular group or individual.

The social contract theory as discussed above holds true for other constitutional jurisdictions because those documents claim to have been adopted by 'the people' of those countries. ${ }^{34}$ In Ethiopia's case, sovereignty is a relatively new concept and the constitutions do not invoke public authority. The first written constitution was 'granted' in 1931 by Emperor Haile Selassie I to

${ }^{29}$ Hume quoted by Riley, supra note 21, at 248, note 7. Hardin, supra note 24, at 299. Kelsen agrees to this statement. H Kelsen, Introduction to Problems of Legal Theory (BL Paulson and SL Paulson, Translation: 1992) at 57.

${ }^{30}$ Rawls's theory of justice is social justice regulating 'a well-ordered society' based on two 'original principles of justice'. The first is the hypothetical 'the original position,' where individuals possess liberty and equality. Rawls equates this principle with the state of nature. The second is, the principle of justice is selected behind 'a veil of ignorance', i.e., no one knows his position in society so that no one is (dis)advataged. Once the principles of justice are agreed upon, laws and institutions are to be established based on this principle, and coercion may be employed in order to maintain such just institution. $\mathbf{J}$ Rawls (1990), A Theory of Justice (Revised Edition, Harvard University Press).

${ }^{31}$ Rawls discuses equality of opportunity in greater detail and in different context. His conclusion is that society is fair only if the least advantage is well off. Ibid.; AM Macleod "Coercion, Justice, and Democracy" in Reidy and Riker (eds), supra note 15, at 67, 68; J Elster "Constitutional Bootstrapping in Philadelphia and Paris" in M Rosenfeld (ed),Constitutionalism, Identity, Difference, and Legitimacy: Theoretical Perspectives (Duke University Press, 1994) at 64.

${ }^{32} \mathrm{M}$ La Torre (2010), Law as Institution (Springer) at 26-29.

${ }^{33}$ H Kelsen, Pure Theory of Law (M Knight Trans., 1967) at 221-224. H Kelsen, General Theory of Law and State (A Wedberg Trans., 1949) at 258-259. Kelsen (1992) supra note 29 , at $57,58$.

${ }^{34}$ The US constitution begins with the clause "We the people of the United States of America..." 
his 'subjects' and the Emperor is recognised to be a sovereign, 'elect of God.' As such, the constitution recognises the Emperor as the sovereign; not the people. The 1955 Revised Constitution maintained that 'tradition' because sovereignty is attached to the crown not to the people or the nation. ${ }^{35}$ The subsequent constitutions made the power closer to the people but they kept it 'abstract' that the notion appears to be of less use to the public than it is for the elite. The Constitution of the People's Democratic Republic of Ethiopia, Proclamation No 1, 1987 ('the PDRE Constitution'), provides that sovereignty belongs to "the working people". ${ }^{36}$

The Constitution of the Federal Democratic Republic of Ethiopia, Proclamation No 1/1995 ('the FDRE Constitution'), on its part, claims to be the product of agreement of "the Nations, Nationalities and Peoples of Ethiopia" and attaches sovereignty to them. ${ }^{37}$ It is further provided that the "Constitution is an expression of their sovereignty" which "shall be expressed through their representatives elected in accordance with [the] Constitution and through their direct democratic participation." ${ }^{38}$

Whether the Ethiopian constitutional order is said to be a product of 'social contract' or otherwise, the doctrine of social contract is effectively challenged from becoming a justification for legitimacy of the state. Nor can it legitimize the constitution. None of our constitutions refer to the individual in the making of the constitution but as subject of the constitution. The ground of legitimacy of the constitution in Ethiopia is as vague as it has ever been. Yet, these constitutions also have another aspect in that they appeal to natural law. For

${ }^{35}$ Article 1 provides that "The Empire of Ethiopia comprises all the territories, including the islands and the territorial waters, under the sovereignty of the Ethiopian Crown. Its sovereignty and territory are indivisible. Its territories and the sovereign rights therein are inalienable. All Ethiopian subjects, whether living within or without the Empire, constitute the Ethiopian people."

${ }^{36}$ This is provided for twice in the preamble, as well as under Art 3. The Constitution under Art 1(1) appears to define the "working people" as "workers and peasants and the [...] intelligentsia, the revolutionary army, artisans and other democratic sections of society."

${ }^{37}$ The FDRE Constitution, Art 8 . The preamble states that the Constitution is ratified by "the Nations, Nationalities and Peoples of Ethiopia." The Preamble of the Constitution begins with the clause "We, the Nations, Nationalities and Peoples of Ethiopia...". Art 8(1) Provides that "All sovereign power resides in the Nations, Nationalities and Peoples of Ethiopia." The reference to "Nations, Nationalities and Peoples" is defined (for the purpose of exercising their right to self-determination but which, unavoidably be extended to other purposes) under Art 39(5) to be "a group of people who have or share a large measure of a common culture or similar customs, mutual intelligibility of language, belief in a common or related identities, a common psychological make-up, and who inhabit an identifiable, predominantly contiguous territory."

${ }^{38}$ Id., Art 8(2) and (3). 
instance, the FDRE Constitution recognises that there are "human rights and freedoms emanating from the nature of mankind" rejecting legal positivism. ${ }^{39}$

\subsection{Sovereignty and its elements as social constructs}

It is agreed that like many grand legal-political doctrines, sovereignty is also a social construct. The difference is the vantage point we look at it from. For instance, when Pusterla -as stated above- holds that sovereignty is an "organised hypocrisy," it is from the perspective of Swiss authorities' claim of sovereignty in the face of deep integration with the European Union. ${ }^{40}$ Likewise, when Biersteker and Weber hold that sovereignty is a 'social construct,' they mean both from the international and the domestic perspective. In further elaboration, they examine the elements constituting the doctrine, each of which, they hold, are socially constructed. ${ }^{41}$

\subsubsection{Territory of the sovereign state}

In international relations, sovereignty becomes complete upon recognition of a state by other states. ${ }^{42}$ A state would extend recognition to another state if that other state has defined territory, the only tangible element. Territory is negotiated and renegotiated; thus, it is a social construct. ${ }^{43}$ For Africa, the issue requires no further comment than to mention the division of Africa based on the 1884 Berlin conference; or the recent secession of South Sudan from the Sudan, and that of Eritrea from Ethiopia, redefining the territories of Sudan and Ethiopia, respectively. For instance, China obliges states dealing with her to, first, recognise Taiwan forms part of the mainland China. A case in point is China's pressure on US President-elect Donald Trump so that US 'One-China' policy would be sustained under his presidency. ${ }^{44}$

\subsubsection{The people of the sovereign state}

Recognition is extended to an organised population inhabiting such territory. Because the identity of any nation is always under constant evolution, such population is manipulated and socially constructed. ${ }^{45}$ The group that is in power

${ }^{39}$ Id., Art 10(1).

${ }^{40}$ Pusterla, supra note 7, at 3-10.

${ }^{41}$ Biersteker and Weber, supra note 9 , at $3 \mathrm{ff}$.

${ }^{42}$ Id., at 12. Kelsen (1949), supra note 33, at 219 - 225.

${ }^{43}$ Biersteker and Weber, supra note 9, at 13.

${ }^{44}$ The Taiwanese President called President-elect Donald Trump to congratulate him on his getting elected for which China lodged a formal complaint with the US over Trump's accepting the call. Trump later assured China that he would continue the US 'One-China' policy.

${ }^{45}$ Biersteker and Weber, supra note 9, at 13. Kelsen (1949), supra note 33, at 233 - 241. For in-depth discussion on how population is socially constructed, see $\mathrm{M}$ Barnett 
defines its identity and that of the 'other' governing through its immigration law, the laws of nationality, manners of recognition of language, culture and other manifestations of identity, which are not new to Ethiopia. Of course, the constitution is the "normative self-construction" of a given society. ${ }^{46}$ For instance, the PDRE Constitution appears to be promoting the "working people" identity. ${ }^{47}$ The FDRE Constitution, on the other hand, promotes ethnic identity based on "Nations, Nationalities and Peoples". ${ }^{48}$ In both cases, the individual is lost in forming sovereignty but it is the subject of the laws of the nation. The Ethiopian people at one time in political history is different from the one in another regime because each wanted to construct a type of people that suits its political ideology. Thus, those who do not want to identify themselves with the identity promoted by the state would not benefit in the distribution of wealth and benefits. $^{49}$

\footnotetext{
"Sovereignty, nationalism, and regional order in the Arab states system" in Biersteker and Weber, supra note 9. Comaroff and Comaroff discuss construction of identity as part of the instrumentality of law. JL Comaroff and J Comaroff, "Reflections on the Anthropology of Law, Governance and Sovereignty" in F von Benda-Beckmann, K von BendaBeckmann and J Eckert (eds), 2009, Rules of Law and Laws of Ruling: On the Governance of Law, Ashgate, at $40 \mathrm{ff}$.
}

${ }^{46}$ C Thornhill (2011), A Sociology of Constitutions: Constitutions and State Legitimacy in Historical Perspective, (Cambridge University Press) at 10. The PDRE Constitution Art 31(1) provides that "any person with both or one parent of Ethiopian citizenship is an Ethiopian." The FDRE Constitution has identical provision under Art 6(1). However, Art 33 appears to have confused matters. Sub-art (1) provides that "no Ethiopian national shall be deprived of his or her Ethiopian nationality against his or her will. Marriage of an Ethiopian national of either sex to a foreign national shall not annul his or her Ethiopian nationality." Sub-art (2) further provides that "every Ethiopian national has the right to the enjoyment of all rights, protections and benefits derived from Ethiopian nationality as prescribed by law." Contrary to the provision of Art 6(1), however, the Ethiopian Nationality Proclamation No 378/2003, Art 20(1) provides that "any Ethiopian national who voluntarily acquires another nationality shall be deemed to have voluntarily renounced his Ethiopian nationality."

${ }^{47}$ PDRE Constitution, Art 9 provides that "the State shall advance the material and cultural development of the working people, which is the primary objective of the economic construction." Art 10(1) further provides that "the State shall ensure [...] the conservation and development of natural resources [...and] it shall guarantee their utilisation for the benefit of the working people." On the other hand, it proudly states the nationalisation of "rural land, urban land and extra houses, and major enterprises of production, distribution and services," (Preamble, para 9, Arts 12,13).

48 The Preamble of the FDRE Constitution asserts that it is a pact among "the Nations, Nationalities and Peoples of Ethiopia." Art 8 vests "all sovereign power" on them. Art 39 further recognises their "unconditional right to self-determination", and Art 43 states their "Right to Development."

49 The PDRE Constitution classifies people into "working people", on the one hand, and "feudal", "anti-revolutionary and anti-socialist imperialist and reactionary forces" on the 


\subsubsection{Exercising authority in the territory and recognition by other states}

In order to acquire recognition, the group in power must exercise such authority over the population in that territory. ${ }^{50}$ There are varying degrees of authority but it is the supreme authority in the territory with no other competing authority that embodies the prize of sovereignty. This authority is socially constructed, ${ }^{51}$ and as already indicated, the allocation of benefits and exercise of authority is done based on the identity promoted by the state. The fact that the three elements are present does not warrant sovereignty. The real deal is recognition by other states which is dominated by western political culture. In fact, it is even related to political economy. ${ }^{52}$ It is good enough to mention the state of Palestine or Somaliland, and until recently, Federal Government of Somalia. The 'state' of Palestine has been there for more than the state of Israel. It met all the basic criteria for statehood but it is not recognised as a state. ${ }^{53}$ State recognition is governed by state practice, which is guided by national interest. ${ }^{54}$

Thus, the overall content of sovereignty is an exercise of domestic authority and external independence, which is the non-interference of other states in the affairs of a given state on matters which are considered 'domestic affairs' of that

other hand. In fact, there were penal provisions that fit into those categories of people. See, for instance, the Special Penal Code Proclamation No 8 of 1974, Art 11, Offences Against the Activities of the Provisional Military Administration Council, and Art 35, Offences Against the Motto "Ethiopia Tikidem." Those provisions would make sense only when they are read along with decisions rendered by the Special Courts-Martial. Thus, as soon as the PMAC came to power it detained all former regime officials for their mere 'identity'. Later, when the EPRDF came to power, it detained the former regime officials, in turn. WPE was disbanded and former members were precluded from candidacy in the new regime running for office. These facts show identities that were suppressed at a particular time in history.

${ }^{50}$ Kelsen (1949), supra note 33, at 255 - 259.

${ }^{51}$ Biersteker and Weber, supra note 9 , at 14,17 . For in-depth discussion on how exercise of authority is socially constructed, see D Dewdney (1996), "Binding Sovereigns: Authorities, Structures, and Geopolitics in Philadelphian Systems" in Biersteker and Weber, supra note 9; A Wendt and D Friedheim "Hierarchy under Anarchy: Informal Empire and the East German State" in Biersteker and Weber (1996), supra note 9.

${ }^{52}$ Biersteker and Weber, supra note 9, at 14, 15.

${ }^{53}$ It is, in fact, recognised by several small western states including Sweden. Conversely, for discussions on how the state of Israel is created out of the Palestinian land, see LV Smith "Wilsonian Sovereignty in the Middle East: The King-Crane Commission Report of 1919" in D Howland and L White (eds), The State of Sovereignty: Territories, Laws, Populations (Indiana University Press, 2009).

${ }^{54}$ Biersteker and Weber, supra note 9, at 12. For an in-depth discussion on Eurocentric political economic content of recognition, see D Strang (1996), "Contested Sovereignty: The Social Construction of Colonial Imperialism" in Biersteker and Weber, supra note 9. 
state. The state that has internal domestic supremacy commands the support of others. 55

\subsection{Locating sovereignty}

Sovereignty is described as supreme political power. In the present Ethiopia, for instance, the holders of such sovereignty -as the Constitution provides- are the Ethiopian Nation, Nationalities and Peoples, assuming they are identifiable group exercising their rights and prerogatives, and discharging their responsibilities. ${ }^{56}$ The Constitution further provides that they exercise their sovereignty through their representatives. ${ }^{57}$

Exercising sovereign power is participation in the development and implementation of essential public policies. There is no evidence, the nations, nationalities and peoples participated in the development of any of those important policy matters, such as, macroeconomic policies or the political ideology the state pursues. However, in recent public discourse, the EPRDF Executive Committee is seen to have undertaken fundamental policy decisions some of which are implemented without the adoption of a legislation. ${ }^{58}$ If sovereignty is exercising supreme political power, it is not found where the

\footnotetext{
${ }^{55}$ For instance, regarding the 1998/99 TPLF internal conflict, the International Development Association (IDA) President in his Report and Recommendations to the Board of Directors of the World Bank, states that "the EPRDF organized a process of consultations among party cadres through local and regional congresses, culminating -in September 2001- in the Fourth Organizational Congress. The wing of the party led by the Prime Minister emerged stronger from the infighting, endorsing a liberal and democratic agenda of reforms. The Report on the Fourth Congress of the EPRDF, which was shared with IDA, sets out the vision and strategy of the Government. It re-confirms the strategy articulated in the I-PRSP [...]. The document also endorses a stronger process of economic liberalization to facilitate the progressive integration of Ethiopia into the world economy." The IDA supported the Prime Minister's agenda and extended substantial loan to Ethiopia. See "Report and Recommendation of the President of the International Development Association to the Executive Directors on a Proposed Credit of SDR 96.2 Million to the Federal Democratic Republic of Ethiopia for an Ethiopia Structural Adjustment Credit (May 15, 2002)", para 4. Kriegel would call such state a "partystate," not a "nation state" (Kriegel, supra note 1 at xi) if it heavily depends on the whims and balance of power in a political party (such as the outcome of EPRDF's $4^{\text {th }}$ Congress).

${ }^{56}$ See, supra note 37.

${ }^{57}$ FDRE Const., Art 8(3).

58 As stated above (in the development of macroeconomic policy of the country in consultation with the World Bank and IMF), it is EPRDF 4th Congress that set the agenda and negotiated through the executive which is fully manned by EPRDF members. When the country was in crises, it is the Executive Committee that made the significant decisions, including the release of 'political prisoners' in "order to expand the political space." Reporter, Amharic Newspaper January 7, 2018, at 3.
} 
Constitution claims it is; its traces are rather found elsewhere. This is probably because of the instrumental nature of sovereignty.

\subsection{Instrumental nature of sovereignty and who exercises power}

The third element of sovereignty is exercising authority. A group in power always asserts that it is exercising legitimate power-authority. It is the dominant group that makes a skilful use of sovereignty. In the modern nation state, the actions of the sovereign are supported by the law. Thus, the powerful group makes use of such law into its advantage that its interests are translated into law. ${ }^{59}$ This is how the social scientists and criminologists, ${ }^{60}$ the political economist, ${ }^{61}$ and the legal theorists ${ }^{62}$ see the use of law through the doctrine of sovereignty to the advantage of a particular group. This follows from the instrumental nature of the social structure, state and sovereignty. Biersteker and Weber succinctly state that "the ideal of state sovereignty is a product of actions of the powerful agents and the resistances to those actions by those located in the margins of power". ${ }^{63}$ Stated otherwise, sovereignty is nothing more "than a convenient label" for those in power. ${ }^{64}$

${ }^{59}$ Comaroff and Comaroff, supra note 45 , at $32 \mathrm{ff}$. They examined the anthropology of law in historical context, how the law is "fetishized", and contend that the law is the battleground and politics is judicialised. They blamed imperialism for 'lawfare,' using the "penal powers, administrative procedures ... [or any other coercive force] to discipline its subjects by means of violence made actual by its own sovereign word." They further argue that "sovereignty" is an exercise of power. "Law-making ....is power-making ...but power [is] the principal of all lawmaking." [citations omitted.] Id., at 36, 39. Kelley asserts that the state, which he also referred to as a 'political reality', "has long been regarded as the medium of modern form of enslavement" based on the experience of historically documented authoritarian regimes. D.R. Kelley "Forward" to Kriegel, supra note 1 , at vii.

${ }^{60}$ B McSherry, A Norrie and S Bronitt (eds.) 2009, Regulating Deviance: The Redirection of Criminalisation and the Futures of Criminal Law, Hart Publishing; JJ Rodger (2008), Criminalising Social Policy: Anti-social behaviour and welfare in a de-civilised society (Willan Publishing); P Scraton, Power (2007), Conflict and Criminalisation (Routledge); HD Barlow and D Kauzlarich (2010), Explaining Crime: A Primer in Criminological Theory Basics of Criminological Theory (Rowman and Littlefield Publishers); GR Skoll (2009), Contemporary Criminology and Criminal Justice Theory: Evaluating Justice Systems in Capitalist Societies(Palgrave Macmillan).

${ }^{61}$ Barlow and Kauzlarich, supra, elaborate Marx's view of law in Chapter 2, at 104-128.

${ }^{62}$ BZ Tamanaha (2006), The Law as a Means to an End: Threat to the Rule of Law (University of Cambridge Press).

${ }^{63}$ Biersteker and Weber, supra note 9, at 3 .

${ }^{64}$ Id., at 5. Kriegel argues that "the principle of despotic government is [...] FEAR. Despotism exhibits political asthenia and juridical anemia, an absence of deliberation; power is all, politics is absent; commandments are absolute, laws are worthless; 
To put it in perspective, the Provisional Military Administration Council ("PMAC"), declared itself as the government promoting the interests of the 'working people' of Ethiopia. ${ }^{65}$ It criminalised anything that goes against the political ideology and against those who are pursuing the ideology while at the same time, it was doing what is criminally prohibited, ${ }^{66}$ but no one was held accountable while it was in power. ${ }^{67}$ Those who fought against the government in power were considered as criminals. ${ }^{68}$ When EPRDF came to power, the conducts of the previous regime turned out to be criminal for which the former government officials were prosecuted and sentenced; while the conducts of EPRDF turned out a 'heroic act' which, if the latter had lost the fight would otherwise remain criminal.

The difference between the two is exercising 'sovereign authority.' After changing seats, the present government in turn criminalises membership to particular groups ${ }^{69}$ It is often the case that the one in power is protected by the aura of sovereignty; and the conducts of the one who is not in power remains to be criminal until it wins the fight for power. In such violent changes of government, Kelsen argues, the old system ceases to be effective and the new system becomes effective because "the basic norm depends on [those] material facts creating the system to which actual behaviour ... corresponds to a certain

implacable oppression and inept administration are the order of the day." [citations omitted.] Kriegel, supra note 1, at 17.

${ }^{65} \mathrm{See}$, generally, the Provisional Military Government Establishment Proclamation No 1 of 1974, and Definition of Powers of the Provisional Military Administration Council and Its Chairman, Proclamation No 2 of 1974.

${ }^{66}$ It adopted a Special Penal Code (Proclamation No 8 of 1974) with retrospective application, Art 2(2). Also see, supra note 49, for illustrations of the types of conducts criminalized.

${ }^{67}$ Firew Tiba "The Trial of Mengistu and Other Derg Members for Genocide, Torture and Summary Executions in Ethiopia" in C Murungu and J Biegon (eds), Prosecuting International Crimes in Africa (Pretoria University Law Press, 2011) at $163 \mathrm{ff}$. Girmachew Alemu Aneme "The Anatomy of Special Prosecutor v. Colonel Mengistu Hailemariam, et. al. (1994-2008)"(2009) in 4 International Journal of Eth Studies 1.

${ }^{68}$ See, for instance, Special Penal Code, Art 45, Political Homicide.

${ }^{69}$ See, Anti-Terrorism Proclamation No 652/2009. Art 7 criminalises participation in and membership to a "terrorist organisation." Whether a particular organisation is a terrorist organisation may be determined by the House of Peoples' Representatives (Art 25), a decision which is fundamentally political. However, while ordinary membership is punishable with 5 to 10 years' imprisonment, leadership or decision making participation entails "rigorous imprisonment from 20 years to life." Until such labelling is removed recently, one of those organisations 'labelled' by the HoPR as a terrorist organisation is Oromo Liberation Front which participated in the formation of the Transitional Government of Ethiopia, post-Dergue. 
degree". ${ }^{70}$ It is for this reason that Pusterla, as stated above, holds that sovereignty is 'organised hypocrisy' because it equates 'despotic domination' with 'legitimate use of power' by confusing the distinction depending on who is asserting legitimacy. ${ }^{71}$

\section{Legitimacy and 'Limited Power'}

Kriegel describes sovereignty as "the state under the rule of law" while Lutz describes it as "a constitutional order that marries justice with power [...] to serve civil society" ${ }^{72}$ An aspect of the notion of sovereignty of the state is exercising authority or legitimate power. The modern understanding of sovereignty of state, therefore, essentially embodies legitimacy. As such, legitimacy is at the heart of the doctrine of sovereignty itself. However, the notion of legitimacy is as elusive as sovereignty itself. Legitimacy is discussed in relation to the creation of the state and, often, when discussed in the context of a constitution, it is about the exercise of authority by way of limiting such power. Thus, Lutz, for instance, argues that in the desire to maintain law and order, "the greatest temptation is to create a central power that is too strong". ${ }^{73}$ But he argues that while we created supreme political power, "constrained supreme power" has paradoxically become a "permanent fact of life". 74 Likewise, Kriegel holds that the "doctrine of sovereignty that establishes the supremacy of the state and the legitimacy of this supremacy does not defend power without limits". ${ }^{75}$

\subsection{The content of legitimacy}

The intuitive understanding of legitimacy is conformity of conduct to a certain required standard, its acceptance by the public affected (bound) by it, that, its outcome is correct. Beetham discusses legitimacy on three levels: the conduct conforms to a certain rule, or that it is normatively justifiable, and it is expressly affirmed or recognised by the subjects, none of which are satisfactorily argued

\footnotetext{
${ }^{70}$ Kelsen (1992), supra note 29, at 59.

${ }^{71}$ Pusterla, supra note 7, at 2, 10. Kriegel, supra note 1, at 3, 5.

${ }^{72}$ See supra notes 2 and 3.

${ }^{73}$ Lutz, supra note 2, at 32.

${ }^{74}$ Id., at $33,35$.

${ }^{75}$ Kriegel, supra note 1 , at 32 . In fact, she argues that sovereignty is a unique notion in that it "has the exclusive capacity to determine itself and to restrain itself from the perspective of the law. [...] Kant's notion of individual morality as self-legislation by a good will is modelled on the politico-legal notion of sovereign power." Ibid.
} 
for how they justify the state or its coercive power. ${ }^{76}$ The scope of the discussion on legitimacy covers both the justifiability of the norms creating the state and those norms adopted by the state so created. ${ }^{77}$ Barnett describes legitimacy as one that "binds one in the conscience" or it carries a "moral duty" of obedience. $^{78}$ It gives the impression that legitimacy is how the ordinary citizen accepts the state; it is, as contended by Raz, a relationship between a state and its subjects. ${ }^{79}$ However, Macleod -who does not make it clear what legitimacy contains- argues that legitimacy cannot be reduced to a "moral defensibility" 80 or a hypothetical consent as pursued by Kant that "a rational person would consent to." 81

\subsection{Foundational legitimacy of the state}

The foundational legitimacy of the state refers to the legitimacy of the state when transiting from state of nature to civil society. A long-accepted justification had been the social contract theory as the secular justification for the existence of the state and its use of coercive power. ${ }^{82}$ However, if the source of legitimacy is the social contract theory in the meaning of the 'consent of the

${ }^{76}$ D Beetham (2013), "Revisiting Legitimacy, Twenty Years on" in J Tankebe and A Liebling (eds), Legitimacy and Criminal Justice: An International Exploration, Oxford University Press, at $20 \mathrm{ff}$.

${ }^{77}$ Barnett classified the legitimacy into two, and focused on the second one. Barnett, supra note 23 , at 130 .

${ }^{78}$ Id., at $115,116$.

${ }^{79}$ In his Frederic R. and Molly S. Kellogg Biennial Lecture in Jurisprudence, Raz contended that there is a difference between sovereignty and legitimacy and he further stated that sovereignty is the relationship between states while legitimacy is the relationship between the state and its subjects. The second Frederic R. and Molly S. Kellogg Biennial Lecture in Jurisprudence by Joseph Raz on the subject of "Sovereignty \& Legitimacy: On the Changing Face of Law, Questions \& Speculations" available at

<https://www.youtube.com/watch?v=VMC9u7PZZCo> last accessed on January 22, 2018. Even though legitimacy is asserted by 'power-holders', Beetham argues that, it can be "improved by policy changes and institutional reform [...as] legitimacy is best understood as a dynamic process of interaction or dialogue between states and their citizens, in which performance and legitimacy respond to each other." Beetham, supra note 76 , at 25,28 .

${ }^{80}$ Macleod, supra note 31, at 66.

${ }^{81}$ Id., at 67. Barnett, supra note 23, at 136.

${ }^{82}$ Beccaria states that "wearied by living in an unending state of war and by a freedom rendered useless by the uncertainty of retaining it, they sacrifice a part of that freedom in order to enjoy what remains in security and calm. The sum of these portions of freedom sacrificed to the good of all makes up the sovereignty of the nation, and the sovereignty is the legitimate repository and administrator of these freedoms." It is this Beccaria holds to be "the foundation of the sovereign's right to punish crimes." Beccaria, supra note 21 , at 9,10 . 
governed,' it could not be achieved both for theoretical ${ }^{83}$ and practical reasons. Barnett argues that, practically, there is no actual unanimous consent and Hardin describes it as "an impossible condition". 84 It is for such lack of actual unanimous consent that Barnett calls the notion of social contract a "fiction" and "fraud on the public". 85

In search of alternative explanations for legitimacy, Hardin argues for a coordination theory or dual convention theory, i.e., a constitution is legitimate by acquiescence. ${ }^{86}$ The public acquiesces to a constitution "because it would be very difficult to organise what would de facto have to be a collective action to topple a going convention or to organise a new one". ${ }^{87}$ The cost of changing the constitution becomes higher because of the inherent predicament of the social structure. However, he further argues that often "our interests are better served by acquiescing in the rule of that constitution than by attempting to change it". 88

There is also a possible argument that a convention is legitimised by a subsequent ('good') conduct of those who administer the constitution which remedies the initial defect. ${ }^{89}$ In this regard, the FDRE Constitution may be a good example in that, it cannot claim initial legitimacy for it missed out several essential power players in the constitutional making. ${ }^{90}$ However, it could have

${ }^{83}$ Hardin distinguishes the notion of ordinary contract as we know from the contract in the 'social contract' that contracts are about defined objects requiring quid pro quo obligation between equal parties, to be completed within a certain period, the terms of which are enforced by third parties. If a constitution is a contract, it is not this type; it is rather a "contract on what contract will mean" Hardin, supra note 24, at 291.

${ }^{84}$ Consent to the constitutional making process is "non-existent and impossible to achieve." Nor are there alternatives to consent. Barnett effectively disqualified the opportunity to vote as consent to obey the law because there are at least few who would oppose the proposition; he disqualified residency in the jurisdiction as consent to obey the law because the cost of relocation is so prohibitive; the consent of the founders is not binding on the present generation; and he showed that acquiescence is not consent. Finally, he contends that benefit received cannot be taken as consent, often, as it is not voluntary. Barnett, supra note 23, at 118-125, 135. Also see Hardin, supra note 24, at 293. Macleod, supra note 31 , at 66.

${ }^{85}$ Barnett, supra note 23, at 112, 113, 115, 118.

${ }^{86}$ Hardin presents acquiescence as part of another theory - coordination theory - not contractian theory. Hardin, supra note 24, at 298

${ }^{87}$ Id., at 297.

${ }^{88}$ Id., at 298.

${ }^{89}$ Elster, supra note 31, at 64.

${ }^{90}$ Adem Kassie Abebe (2013), "From the 'TPLF Constitution' to the 'Constitution of the People of Ethiopia': Constitutionalism and Proposals for Constitutional Reform" in MKMbondenyi and TOjienda (eds), Constitutionalism and Democratic Governance in Africa: Contemporary Perspectives from Sub-Saharan Africa, PULP at 54-57. Also, see 
made that 'good' by containing provisions that promote and protect the interests of those groups missing out in the constitutional making, and enforcing those provisions in keeping with the constitutional promise.

Yet, foundational legitimacy cannot be secured by complying with certain rules of standards for there were no a priori rules. ${ }^{91}$ Kelsen in his theory of state and law, argues that a sub-constitutional norm may be validated by its conformity to the constitution. The constitution cannot be validated; it is our presupposition. Likewise, Dunn argues that legitimacy is "a presupposition of every actually existing state". ${ }^{92}$ Owing to factors including the practical-logical difficulty of showing such legitimacy, the debate on initial legitimation seems to imply that "power at some point is usurped or taken by force". ${ }^{93}$

\subsection{Second level legitimacy}

After interrogating the social contract source of the binding nature of the constitution, Barnett goes on to classify the norms into those binding on the state and those binding on the individual. ${ }^{94}$ His enquiry of legitimacy focuses on subconstitutional norms adopted based on authority claimed from the constitution. ${ }^{95}$ He argues that such legislation could be legitimate if it is seen as "a product of procedural assurances that legal commands are not unjust". ${ }^{96}$ Justice is "the only principle" which, he contends, "everybody can be presumed to agree to" ${ }^{97}$ In this manner, he shifts the debate on legitimacy, from one of foundational legitimacy to that of procedural fairness of the commands of the state claiming constitutional authority, and justice. He further argues that his proposed argument is not a particular type of theory of justice but stands "between validity and justice". ${ }^{98}$ Dunn, on the other hand, connects legitimacy with

Editorial of Addis Zemen Newspaper (Title in Amharic) July 2, 1991 "One that has to be taken from the Perspective of Public Interest," [translation mine] at 2.

${ }^{91}$ Elster, for instance, argues as the convention could not logically convene itself, the conventions both in Paris and Philadelphia were convened by those who were part of the problem to find a solution. However, once they called on the convention, their preexisting orders were not binding anymore. Elster, supra note 31, at 66, 67. This is absolutely different in the Ethiopian case. Both in the formation of the PMAC and FDR Ethiopia, the conventions could not be called by any external authority, but by the convention itself, the victor. The logical impossibility of the foundational legitimacy presented by Barnett fits here. Barnett, supra note 23, at 121 .

${ }_{92}$ Dunn, supra note 20, at 11.

${ }^{93}$ Riley, supra note 21; Hardin, supra note 24, at 299; also see Kriegel, supra note 1, at 2124

${ }_{95}^{94}$ Barnett, supra note 23, at 130.

${ }^{95}$ Id., at 115 .

${ }^{96}$ Id., at 113 .

${ }^{97}$ Id., at 137.

${ }^{98}$ Id., at 114. 
democracy. He argues that legitimacy is not a matter of fact; it is rather a matter of judgment that constantly changes. ${ }^{99}$ For him, legitimacy is a "political decision" which is legitimized through democracy. ${ }^{100}$ Likewise, Macleod argues, legitimacy is based on democracy and justice, and in his subsequent discussion, the two notions merge in effect. ${ }^{101}$

In the Kelsenian theory of validity, the sub-constitutional norm is valid in so far as such norm conforms to the legislation that is higher in hierarchy. For instance, in the Ethiopian context, a directive is valid if it is in conformity with the Regulations that authorises its adoption which in turn is validated if it is adopted in conformity with the proclamation. Finally, a proclamation is valid if it is adopted in conformity with the Constitution. This conformity is both procedural and substantive.

Legitimacy has extra content other than rules of validity -according to Barnett, it must be "binding in conscience" of the individual. ${ }^{102}$ Barnett borrows a clause from the US Constitution and argues that in order for those laws to be binding on the ordinary citizen, such laws must be "necessary and proper". ${ }^{103}$ In order for coercive laws to be binding on citizens, such laws must be 'necessary' to protect the rights of others. However, such laws would be 'proper' in so far as they do not violate the pre-existing rights of persons on whom they impose coercive duties. ${ }^{104}$ Such pre-existing rights, according to Barnett, are "natural rights". ${ }^{105}$

\footnotetext{
${ }^{99}$ Dunn, supra note 20 , at 8.

${ }^{100}$ Id., at 9, 10.

${ }^{101}$ Macleod, supra note 31, at $63 \mathrm{ff}$.

${ }^{102}$ Barnett, supra note 23, at 113, 114, 142.

${ }^{103}$ Id., at $127,144$.

${ }^{104}$ Id., at 142
}

105 Earlier, he argues that if there is an assumption that the social contract is based on consent, then it presupposes that there is a pre-state and pre-law right called natural right. People need to have rights before the foundation of a legal system. Barnett, supra note 23 , at 136,142 . Donnelly rejects this assertion that "rights are social" as well as legal. They are "grounded not in the descriptive account of the psycho-biological needs but in a prescriptive account of human possibility." [emphasis in the original.] Thus, in the absence of law, there can never be right. J Donnelly (2006), "Human Rights" in JS Dryzek, B Honig and A Phillips (eds), The Oxford Handbook of Political Theory, Oxford University Press, at 603. 


\section{Constitution and Constitutionalism: Structural Limitation on the Coercive Power of the State}

The constitution is a statement of the "self-conception" of society; ${ }^{106}$ it is an instrument of identity but it is also used as an instrument of asserting sovereignty at the national level. ${ }^{107}$ The very notion of constitution is having a limited government. ${ }^{108}$ Generally stated, the application of the constitution as limiting the power of the state is referred to as constitutionalism; it is applying the constitution in its entirety and being bound by it. ${ }^{109}$ The constitution ideally contains, among others, structure of the government, its powers and a bill of rights. ${ }^{110}$ Thus, the restriction on the power of the government is broadly categorised into structural and substantive. Structural limitations are the subject of this section while the substantive limitation (with regard to the bill of rights), is the subject of the next section.

This section deals with structural limitation on the power of the state which is further classified into institutional and normative. The institutional structural division of state power among the three branches of government relates to competence. The normative structure relates to the structure of the constitutional principles and values, and how the bill of rights fits into that normative structure in the normative hierarchy.

\subsection{Institutional Structural Limitations}

The power of the government is apportioned among the three branches principally between the legislature and the executive. ${ }^{111}$ This is essentially designed with intent to limit the abuse of state power against the people whom it is supposed to serve. ${ }^{112}$ Therefore, the structural framework is fundamental. Thus, one branch of the government does not intrude into the sphere of the

106 Thornhill, supra note 46, at 10.

107 Kelsen (1949), supra note 33, at 258 - 259. The political theorists conveniently pass matters of local legitimacy of sovereignty to the constitutional document. Biersteker and Weber, supra note 9, at 9.

${ }^{108}$ Lutz states that constitution is an instrument of justice and fairness to achieve the 'common good'. For Lutz, constitutionalism has three general elements - culture, power and justice. Lutz, supra note 2, at 11, 17, 18. G. Sartori (1962), "Constitutionalism: A Preliminary Discussion”, 56 The Am PolSci Rev 853, at 855, 860.

${ }^{109}$ Id., at 26, 37.

${ }^{110}$ Kelsen (1949), supra note 33, at 260 - 269. Thornhill, supra note 46, at 10-11. Sartori, supra note 108 , at 856 .

${ }^{111}$ For detailed discussion see, CM Fombad (2016), "An Overview of Separation of Powers under Modern African Constitutions" in CM Fombad (Ed), The Separation of Powers in African Constitutionalism, Oxford University Press; Kelsen (1949), supra note 33, at 269 -272 .

${ }^{112}$ Bhagwat, supra note 21, at 61. 
other. This structural aspect of the restriction of power also includes matters, such as, jurisdiction or competence. ${ }^{113}$

The FDRE Constitution under Art 55(5) provides that the House of Peoples' Representatives is specifically authorised to adopt a penal code. Thus, should the government decide to criminalise certain conducts, such criminalisation should be included in such penal code. ${ }^{114}$ The Constitution under Art 51 lists the power of the Federal Government. As can be understood from the reading, all administrative and regulatory power is reserved for the Federal Government. Art 55(1) is a general legislative power provision in that, the House has the power to legislate on matters that are reserved for the Federal Government. Thus, the House adopts almost all legislation based on this provision. ${ }^{15}$ Several of those areas reserved for the Federal Government on which the House may adopt legislation are specifically provided for under Art 55(2) and the subsequent provisions. However, there is no criminal regulatory power reserved for the Federal Government under Art 51. Thus, Art 55(1) cannot be understood to authorise the House to adopt penal provisions to enforce administrative matters.

The legislative power of the House is different from the administrative and regulatory power of the Federal Government. Leaving that argument for constitutional lawyers, it is evident that if the House is given the power to adopt a penal code, and it is historically evident that such penal code is of civil law tradition, which is comprehensive, there is no reason for the Constitution to authorise the adoption of other penal provisions in piecemeal legislation outside the penal code. If new things arise and a new provision needs to be added, or a provision needs to be changed, it is the penal code that needs to be amended. Further, because of economy of words in a constitution, it does not authorise a given conduct twice.

The adoption of regulatory provisions may be seen in light of the provisions of the Criminal Code, Art 3. Historically, it is meant to authorise the adoption of a regulation that may be adopted in the manner Book III, on Petty Offences, is

\footnotetext{
${ }^{113}$ Fombad, supra note 111, at 61.

${ }^{114}$ It may also be contended that such legislation the Constitution referred to as a 'penal code,' may not be named otherwise, such as, 'criminal code.'

115 See, for instance, Banking Business Proclamation No 592/2008, Value Added Tax Proclamation No 285/2002, Federal Tax Administration Proclamation No 983/2016, The Ethiopian Federal Government Procurement and Property Administration Proclamation No 649/2009, and Commercial Registration and Licencing Proclamation No 980/2016, each of which contain lengthy imprisonment sentences.
} 
written. ${ }^{116}$ Those regulatory proclamations may provide for the operative facts (those prohibited or proscribed conducts), which, based on the principle of legality, are required to be published in the Negarit Gazeta. However, administrative penal provisions cannot be outside of the Penal/Criminal Code. The joint reading of the Criminal Code Arts 3 and 343, or Arts 3 and 433, or Arts 3 and 434 supports such position.

\subsection{Normative Structural Limitation}

A constitution is the supreme law, and it includes provisions that have direct and indirect application. Provisions of a constitution that have indirect application also put the sub-constitutional norms in a certain order. Those norms relating to the structure of constitutional and sub-constitutional norms are called postulates (principles). ${ }^{117}$ Avila classifies postulates into hermeneutic, normative and applicative postulates. ${ }^{118}$ Their application may be seen both in the legislative as well as in the adjudication process regarding the content and limitation of the bill of rights. ${ }^{119}$

One of the most important hermeneutic postulates is the postulate of the "unity of legal order", which also includes the postulates of coherence, consistency and hierarchy under it. ${ }^{120}$ These postulates require that the constitutional norm at the top should cohere to each other and all subconstitutional norms should conform to such constitutional norm. Some of the applicative postulates include proportionality, reasonableness and prohibition of excess. ${ }^{121}$ Avila argues that weighing is a non-specific postulate as it is "void of substantive or formal criteria" much broader than 'proportionality' and 'reasonableness'. 122

In this regard, Art 9(1) specifically provides that the "Constitution is the supreme law of the land. Any law, customary practice or a decision of an organ of state or a public official which contravenes this Constitution shall be of no effect." This provision asserts the unity of the legal order. Likewise, Art 85 provides that "any organ of Government shall, in the implementation of the Constitution, other laws and public policies be guided by the principles and objectives specified under" Chapter Ten. The bill of rights is guided by the jurisprudence and practice of the international bill of rights both for the

\footnotetext{
${ }^{116}$ See, Simeneh Kiros Assefa and Cherinet Hordofa Wetere (2017), “'Over-

Criminalisation': A Review of the Special Penal Legislation and Administrative Penal Provisions in Ethiopia" 29 Journal of Ethiopian Law 49.

${ }^{117} \mathrm{H}$ Avila (2007), Theory of Legal Principles (Springer) at $83 \mathrm{ff}$.

${ }^{118}$ Id., at 3. Hermeneutic postulates are "related to the interpretation of texts." Id., at 54.

${ }^{119}$ R Alexy (2000), "On the Structure of Legal Principles" in 13 Ratio Juris 294, at 294.

${ }^{120}$ Avila, supra note 117 , at $85,87$.

${ }^{121}$ Id., at 92.

${ }^{122}$ Id., at 99.
} 
determination of their content and such methods of interpretation. ${ }^{123}$ Therefore, the constitutional adjudication process is guided by those postulates and the House is required to comply with those competence rules and normative structural limitations.

\section{Exercising (Sovereign) Authority}

The doctrine of sovereignty is developed to justify the exercise of power, although it relates to limited power (authority). Normatively described, it is the violence power of the state which is expressed in areas, such as, criminal law, tax law and conscription. ${ }^{124}$ In the modern notion of state, sovereignty is said to be vested in the people who delegate their representatives to act on their behalf, and such delegated power is exercised through legislation. Thus, criminal lawmaking (criminalisation) is one important consequence of exercise of sovereign authority.

\subsection{Criminalisation and the common (public) good}

Criminalisation is declaration of conduct criminal. Criminal law is the most intrusive form of state action and is revealing of the coercive nature of the state. $^{125}$ Criminal norms are conditional statements having both the operative facts and the consequence; ${ }^{126}$ the operative facts state the prohibited conduct and their violation entails the consequence, a punishment. As such, they give the individual a choice; thus, conducts complying with criminal norms are not normally taken as coerced actions. ${ }^{127}$ Beccaria states that men are moved more by the motive to avoid pain than by the pursuit of pleasure; ${ }^{128}$ therefore, compliance is only for the purpose of avoiding the consequent pain for violation of a criminal norm.

Sovereignty is manifested in making laws, establishing institutions, and imposing sanctions. It is so big a power that without a proper limit, it is "a slippery slope into authoritarianism". ${ }^{129}$ More so, the criminal law, the most

${ }^{123}$ Article 13(2) provides that the bill of rights "shall be interpreted in a manner conforming to the principles of the Universal Declaration of human Rights, International Covenants on Human rights and international instruments adopted by Ethiopia."

${ }^{124}$ Leiser, supra note 15 , at 37,38 .

${ }^{125}$ N Persak,Criminalising (2007) Harmful Conduct: The Harm Principle, Its Limits and Continental Counterparts (Springer) at 1.

${ }^{126}$ G Hallevy (2010), A Modern Treatise on the Principle of Legality in Criminal Law (Springer) at 15-17.

${ }^{127}$ Macleod, supra note 31, at 64; DA Reidy and WJ Riker (2008), "Introduction" in Reidy and Riker (eds), supra note 15 , at 3, 5 .

${ }^{128}$ Beccaria, supra note 21, at 31, 48, 49, 63.

${ }^{129}$ Kriegel, supra note 1 , at 16. 
effective social control tool, ${ }^{130}$ is always a suspect for unjustifiably limiting the rights of the individual. ${ }^{131}$ Whatever the justification, the state claims that it uses the criminal law for the 'common good', ${ }^{132}$ which is the ultimate public good. The common good, as defined by Beccaria, is the peaceful social existence of individuals. ${ }^{133}$ In order for criminalisation to be legitimate, it needs to meet both the substantive and procedural requirements of legislation, and must comply with limitations on such power of the government. Therefore, the principle of legality, for instance, requires that both the operative facts and the consequence be declared.

\subsection{Doctrinal limitations to criminalisation}

The structural limitation discussed under section 3, are institutional and normative structure. The structural limitation on the power of the government had once extended to other normative aspects of constitutions. Thus, a bill of rights used to be taken to have the same structural effect. This section rather focuses on the doctrinal limitations on the criminalisation power of the state.

Criminalisation is normative declaration of criminal conduct. ${ }^{134}$ The state does not have a free hand to criminalise conduct at whim. In the positivisation of the criminal law, conduct may be criminalised when two conditions are met. The positive condition for criminalisation is that the legal interest must be one that demands the protection of the criminal law, and the negative requirement is that, the purpose that requires the protection of the criminal law cannot be achieved by other means, such as, administrative measures and civil actions. ${ }^{135}$

${ }^{130}$ See, for instance, The Penal Code Proclamation of 1957, Preface, para 2. Vagrancy Control Proclamation No 384/2004, Preamble, para 2. Also, see RF Meier and WT Johnson (1977), "Deterrence as Social Control: The Legal and Extralegal Production of Conformity" in 42 Am Sociological Rev 292.

${ }^{131}$ Macleod, supra note 31, at 66.

${ }^{132}$ See supra note 21.

${ }^{133}$ Beccaria, supra note 21, at 24, 25.

${ }^{134}$ Sometimes, criminalisation is said to have also included enforcement of the criminal law in addition to the legislative proscription. See, for instance, N Lacey (2009), "Historicising Criminalisation: Conceptual and Empirical Issues" in 72 Modern L Rev 936, at 950. However, that falls under discussions, such as, uniform (equality of) enforcement and selective prosecution.

${ }^{135}$ For the positive and negative requirements of criminalisation, see, generally, Simeneh and Cherinet, supra note 116; MD Dubber (2005), "Theories of Crime and Punishment in German Criminal Law", 53 Am J of Comp L 679; S Mir Puig (2008). "Legal Goods Protected by the Law and Legal Goods Protected by the Criminal Law, as Limits to the State's Power to Criminalize Conduct", 11 New Criminal Law Review: An International and Interdisciplinary Journal 409; D Husak (2004), "The Criminal Law as Last Resort", 24 Oxford J. of L Studies 07. 
These principles are incorporated as legislative promise into Art 1 of the Criminal Code. Such legislative promise is made by the legislature and there is a risk that it may be changed at the will of the legislature itself. Therefore, the limitations on the criminalising power of the state must be found in a higher norm, the Constitution. In addition to the formal limitations discussed earlier, the substantive restriction highlighted in the following section is important.

The enquiry into the justifiability of the state's use of its coercive power relates both to the content of the conduct that is criminalised and the consequences for violations. ${ }^{136}$ However, there is also a legitimate enquiry into the justifiability of the lawmaking process. This relates to the validity of the law and whether procedural justice is achieved. ${ }^{137}$

\section{Fundamental Rights as Limits to Sovereignty}

Earlier theorists considered the social contract, natural rights and other premises as pre-state and pre-law, which justify the right exercised in the formation of the state. ${ }^{138}$ However, as rights are social, some argue that they cannot exist in the pre-state. ${ }^{139}$ In a modern nation state, the constitution is the one that creates and legitimizes the state while it is also meant to limit the power of the state. This section deals with the bill of rights as both structural and substantive limitations to the power of the state.

\subsection{Bill of rights as structural limitation on the power of the state}

The notion of a constitution is developed as part of the project of a limited government. The concept of separation of power is introduced in order to achieve this limit on government power. Thus, when the bill of rights was proposed as amendments to the US Constitution, for instance, there had been objection to them because the structural limit on the government was believed to be sufficient. ${ }^{140}$

The opponents of a bill of rights had argued that state power delegated to the state is enumerated power; thus, it is inherently limited that it needs no further limit. ${ }^{141}$ Because the government's power was believed to be limited to those expressly provided for in the constitution, the introduction of a bill of rights

\footnotetext{
${ }^{136}$ Macleod, supra note 31, at 65.

${ }^{137}$ Id., at, 67 . This includes non-discriminatory law and non-discriminatory application of such law.

${ }^{138}$ Barnett, supra note 23, at 136, 142. Donnelly, supra note 105, at 604, 617.

${ }^{139}$ Donnelly, supra note 105 , at 603 .

${ }^{140}$ Bhagwat, supra note 21, at 39.

${ }^{141}$ Id., at 38,46 . The essence of their argument is that there is no distinction between the purpose of the bill of rights and the structural separation of power. Id., at 39.
} 
rather was said to be 'dangerous' in that whatever is not provided for in the bill of rights might be deemed to be allowed. ${ }^{142}$ There had been a similar objection to the introduction of the bill of rights at the French Assembly based on the assertion that granting rights to citizens is dangerous. It had been counter-argued that the bill of rights is a restatement of the truth and "the truth can never be dangerous". ${ }^{143}$ The proponents of the introduction of the bill of rights won the debate in both countries, and a bill of rights is incorporated both in the US and the French constitutions. ${ }^{144}$

The content of the amendments introduced to the American constitution give the impression that they are about structural limitation rather than individual autonomy. ${ }^{145}$ As stated by Bhagwat, the first amendment provides that "congress shall make no law..." negatively impacting three major activities, including the commonly known "abridgement of the freedom of speech or the press". ${ }^{146}$ Other subsequent amendments, the second amendment on the right to bear and keep arms, the third amendment on privacy, the fourth amendment on protection against unreasonable search and seizure, are as good as the structural limitations on the power of the government because they focus on the collective exercise of the right to limit their government and not as rights for the individual autonomy. ${ }^{147}$

Those rights incorporated in the Fifth Amendment to the Eighth Amendment of the US Constitution address matters in the administration of the criminal justice system, such as, due process, prohibition of double jeopardy, selfincrimination clause, confrontation and the compulsory process, which were not considered serving a different purpose. ${ }^{148}$ These rights require the government "when employing its ultimate coercive power" that it does not abuse its power by unfairly targeting individuals or not to use "cruel or unusual punishment." 149

\subsection{Bill of rights as substantive limitation on the coercive power of the state}

\subsubsection{In the context of adjudication - The principle theory of rights}

Kriegel makes a distinction between 'absolute power' and 'power without limitation' and she argues that sovereignty is absolute power; but it is not a

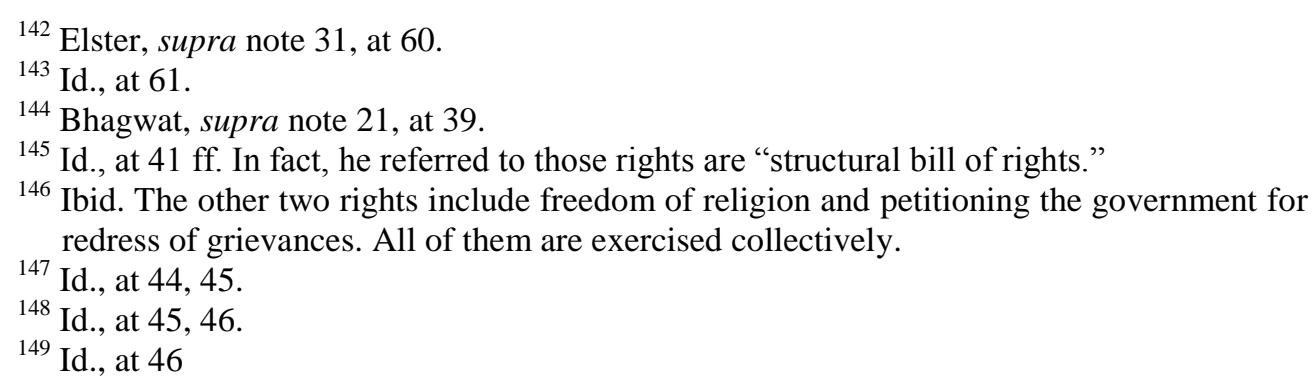


power without limitation. The "omnipotence of the state" is limited by law which meanwhile ensures individual rights. ${ }^{150}$ Today, the bill of rights is seen as a substantive limitation to the right to legislative power. Political theorists see the bill of rights as recognising the rights of the individual to be free from government coercion within a certain sphere. ${ }^{151}$ Legal theorists, on the other hand, see the bill of rights further as legal principles within the constitutional framework. As such, they opine that fundamental rights are principles. ${ }^{152}$

Constitutional principles are not only those that are directly applicable rules but also normative judgments, ${ }^{153}$ such as, the bill of rights. Those normative judgments or principles have unique properties that distinguish them from other norms that they are "optimisation commands' ${ }^{154}$ When principles are described as optimization commands, it means, they are "applicable in several degrees" or that they impose the "duty of realisation to its maximum extent but only to its necessary extent". ${ }^{155}$ Principles are not necessarily different from rules in terms of content that they may have both the operative facts and consequences, except they are higher level abstractions. ${ }^{156}$ However, they are different from other norms, at least, in their application and in the event of normative conflict.

Alexy, in his 'principle theory' thesis argues that, fundamental rights need to be treated as principles because principles require optimisation and during collision they further require weighing each principle against the other. ${ }^{157}$ Avila disagrees with this argument in that weighing is "not exclusive method of principle application"; nor would principles have "weight dimension". ${ }^{158} \mathrm{He}$ asserts that most principles are silent regarding their own weight. Weight is not "empirical quality of principles" nor is it related to the norm; it rather relates to "the reasons and goals which they refer to" which the judge values. ${ }^{159}$ However, elsewhere, he describes how conflict is resolved in a manner showing principles actually have weight. He states that when two principles collide, they are not

\footnotetext{
${ }^{150}$ Kriegel, supra note 1, at 32.

${ }^{151}$ I Berlin (1997), “Two Concepts of Liberty” in RE Goodin and P Pettit (eds), Contemporary Political Philosophy: An Anthology (Blackwell Publishers,).

${ }^{152}$ Alexy, supra note 119.

${ }^{153}$ J Sieckmann (2013), "Legislation as Implementation of Constitutional Law: A Foundation for the Demand of Legislative Rationality" in LJ Wintgens and AD Oliver-Lalana (eds), The Rationality and Justification of Legislation: Essays in Legisprudence (Springer,) at 107, 108.

${ }^{154}$ Avila, supra note 117, at 10, 20. Alexy, supra note 119, at 294.

${ }^{155}$ Avila, supra note 117, at 10, 28. Alexy, supra note 119, at 295.

${ }^{156}$ Avila, supra note 117 , at 17.

${ }^{157}$ Alexy, supra note 119, at 295 - 298.

${ }^{158}$ Avila, supra note 117, at 20.

${ }^{159}$ Id., at 25 - 28.
} 
applied as 'all or nothing; and "the principle with relative higher weight will superpose" without nullifying the other. ${ }^{160}$

There is a general consensus that fundamental rights have to be seen as principles. ${ }^{161}$ Whether we are weighing the principles or their goal, there is consensus on the method of weighing. Gardbaum states a two-step approach first identifying the right implicated and infringed, and determining the scope of the right. ${ }^{162}$ In this step, he discusses specific and general limitation clauses including the positive and negative obligations of the state regarding a particular right. It is to be noted that criminalisation involves classical state-citizen relationship which requires a state to carry a higher burden in order to have its policy maintained.

The second step is considering the relevance and strength of the conflicting public policy that is said to implicate the rights of the individual. ${ }^{163}$ This step involves a three-prong analysis of the principle of proportionality -suitability of the means used by the state, whether the means used is necessary and the least intrusive, and whether the means is proportional considering the relative weight of the right and the conflicting public policy. ${ }^{164}$

Therefore, when the state adopts a particular public policy that implicates fundamental rights, the adjudicating body, after identifying the conflicting fundamental rights, and determining the scope of such right, evaluates the relative importance of the two principles. Often, when the state adopts a public policy, it is alleged to be for the "common good." One such public policy is criminalisation of conduct. The constitutional adjudicating organ first identifies the right that is implicated by the legislation that criminalises a given conduct. It

${ }^{160} \mathrm{Id}$, at $9,20$.

${ }^{161}$ Alexy, supra note 119, at 295 ff.; S Gardbaum "The Structure and Scope of Constitutional Rights" in T Ginsburg and R Dixon (eds), Comparative Constitutional Law (Edward Elgar Publishing, 2011) at 387.

162 Gardbaum, supra note 161, at 388, 389; B Schlink (2012), "Proportionality" in M Rosenfeld and ASajo (eds), The Oxford Handbook of Comparative Constitutional Law (Oxford University Press,) at $721 \mathrm{ff}$.

${ }^{163}$ Gardbaum, supra note 161, at 388.

${ }^{164}$ Id., at 390. Avila states this differently. "The first stage is to prepare to weigh ....all the elements of the arguments ought to be analysed as exhaustively as possible; ...the second stage is that of performing the counterbalance ... where the relation found between the counterweighed elements will be justified. And the third stage is that of to rebuild counterbalance ... by formulating relation rules, including those precedence among the counterweighed elements, expecting them to be valid beyond the case." He further argues that "practical accordance is the guiding purpose of the counterweighing." And that the postulates of reasonableness and proportionality help the optimization of the constitutional norms. [emphasis in the original] Avila, supra note 117, at 100, 101. 
could be the right to equality, free speech, the right to pursue a livelihood of one's choice, freedom from particular type of punishment, etc.

For instance, Art 433 of the Criminal Code ${ }^{165}$ criminalises doing business without a license. ${ }^{166}$ In this regard, Art 49 of the Commercial Registration and Business Licensing Proclamation No 980/2016 provides for punishments of various degrees. For instance, sub-art (2) provides that:

"any person engaged in business activity without having a valid license or any business person who has been engaged in a business out of the scope of his business license shall, without prejudice to the confiscation of merchandise, service provision and manufacturing equipments [sic], be punished with fine from Birr 150,000 (one hundred fifty thousand) to Birr 300,000 (three hundred thousand) and with rigorous imprisonment from 7 (seven) years to 15 (fifteen) years". ${ }^{167}$

In order to evaluate whether such penal provision should be maintained, the first step would be identifying the constitutional right implicated by such provision and determining the scope of such right. This provision may have implicated several other constitutional rights but what readily comes to mind is the right of individuals to engage in livelihood of their choice. Art 41(1) of the FDRE Constitution provides that "every Ethiopian has the right to engage freely in economic activity and to pursue a livelihood of his choice anywhere within the national territory." Because this provision gives the impression that it focuses on the rights to movement within the national territory, we need to read further the provisions of sub-art (2) which provides that "every Ethiopian has the right to choose his or her means of livelihood, occupation and profession." The adjudicating organ needs to define the scope of this right and whether there is any limitation to it, be it general or specific.

${ }^{165}$ Art 433 of the Criminal Code provides that "whoever performs any activity, in respect of which a license is required by law or regulations, without obtaining such license or by exceeding the limits of his license, is punishable according to the circumstance of the case with simple imprisonment or fine; or with rigorous imprisonment not exceeding five years and fine."

166 This provision may be considered as inclusion of the provisions of the Commercial Registration and Licensing Proclamation No 67/1997, Art 49, which provides that "without prejudice to administrative measures that may be taken by the Appropriate Authority and unless the offense is punishable without more severe penalty under other applicable laws: (1) Any person who engages in commercial activity without having a valid business license shall be punished with fine equal to double the revenue estimated to have been earned by him during the period of time he operated the business without a valid license, and with imprisonment from 3 up to 5 years."

${ }^{167}$ This is what was provided for in the Commercial Registration and Licensing Proclamation No 686/2010, Art 60. 
The second step would be counterweighing this right of the individual to engage in livelihood of his choice and the state's policy of maintaining legality in the commercial activity by requiring everyone to engage in business activities only upon securing a 'valid license' at the pain of such criminal punishment. This second step, involves the three-prong approach of weighing the two conflicting principles.

The first test is whether such 'severe' criminal punishment on top of the administrative measure authorised in the proclamation is an appropriate means of achieving the state's end. The end the legislation is meant to achieve is "to put in place a fair, modern, fast and accessible system of commercial registration and business licensing services". ${ }^{168}$ There is no justification provided in the statute regarding the need to criminalise such conduct. The closest statement to justification states that it is meant "to support commercial registration and licensing activities with modern technology in order to make them suitable for data management, to combat illegality". ${ }^{69}$ [emphasis added.] Criminalisation appears to be remotely relevant to the state's objective stated in the Commercial Registration and Licensing Proclamation.

The second test is whether this criminal punishment is necessary, in addition to those administrative measures (that are the least intrusive means to achieve the state's end). This requirement may be seen in light of the doctrinal limitations to criminalisation, the negative requirement, ultima ratio, i.e., whether the state's objective may be achieved by other less intrusive means, such as, administrative measures and civil actions. There is no evidence which shows that the administrative measures were not sufficient to achieve the objective of the state.

The third test relates to whether such restriction to the right of the individual -to engage in livelihood of his choice at the pain of such 'severe' punishmentis proportional to the state's public policy objective. In order for the adjudicator to maintain such penal provision, it must find all these three points in the affirmative. Otherwise, the legislation would be struck down as unconstitutional, assuming there is a strong constitutional review.

${ }^{168}$ Commercial Registration and Licensing Proclamation No 980/2016, Preamble, para 1 - 3.

169 According to the previous proclamation, the objective of the statute is "to create conducive environment in every field of commercial activity in line with the free market economic policy" Proclamation No 686/2010, Preamble, para 1. Of course, this has to be seen in the context the legislation is adopted - it is adopted as the World Bank loan conditionality to create a business friendly regulatory and administrative environment. Thus, they focus on justifying the proclamation in a more palpable manner to the lenders than justifying criminalisation. 


\subsubsection{In the context of legislation - Legislative rationality}

The constitution contains provisions that have direct application as well as normative judgments. Those provisions that have direct application limit the power of the government. However, the provisions that contain normative judgments help the lawmaker to adopt rational public policy. Sieckmann argues that, in order for rationality to guide the lawmaker in the law-making process, such requirement needs to have a constitutional base. ${ }^{170}$ This appears to fit Barnett's two level discussion on constitutional legitimacy wherein he shifted his quest for legitimacy from the constitution to sub-constitutional norms on account that the constitution binds the government while it is those subconstitutional norms adopted based on such constitution that bind the citizen. ${ }^{171}$

Sieckmann argues that rationality has a constitutional foundation at least for "the application of fundamental rights principles". ${ }^{172}$ His argument is based on seven theses. Aligned with the principle theory of Alexy and Gardbaum, his first thesis is based on the assumption that fundamental rights are provided for in the constitution. And therefore, he opines that "constitutional law includes not only directly applicable norms, but also ideals or principles that figure as normative judgments in the procedures of balancing". ${ }^{173}$ His second thesis follows from his first thesis of rationality of legislation that "the legislature is the primary addressee of the requirement to balance constitutional principles". ${ }^{174}$ This is made evident in Fuller's 'the inner morality of law', ${ }^{175}$ or that of the German notion of the 'duty to reflect'. ${ }^{176}$

\footnotetext{
${ }^{170}$ Sieckmann (2013), supra note 153 , at 107, 108.

${ }^{171}$ Barnett, supra note 23, at 130, 131.

${ }^{172}$ Sieckmann (2013), supra note 153, at 108.

${ }^{173}$ Ibid.

${ }^{174}$ Id., at 109.

${ }^{175}$ Lon Fuller's discussion on the eight requirements for validity of law relate to rational legislation, except they focus on validity of law rather than rationality of lawmaking.

${ }^{176}$ The duty to reflect requires a rational and informed choice from the lawmaker and to continuously evaluate a decision. It has five elements - "(1) a duty to establish the facts, (2) a duty to balance, (3) a duty to prognosis or prospective evaluation, (4) a duty to take future circumstances into consideration and (5) a duty to correct legislation at a later stage, or retrospective evaluation." LJ Wintgens "Legislation as an Object of Legal Theory: Legisprudence" in LJ Wintgens (ed.) 2002, Legisprudence: A New Theoretical Approach to Legislation: Proceedings of the Fourth Benelux-Scandinavian Symposium on Legal Theory, Hart Publishing, at 32, 33. Wintgens further elaborated those subjects as 'Duties of Power' juxtaposing with the principle based legislation. See Wintgens (2012), supra note 19, at $294 \mathrm{ff}$.
} 
His third thesis is that the construction of "fundamental rights as principles to balance against competing principles is a requirement of democracy itself". ${ }^{177}$ It is discussed in the adjudication aspect of the construction of the bill of rights (which is also part of the first thesis) that when principles collide, the principle with a relative higher weight would superpose. In this process, it is evident that there is evaluation of competing interests. Sieckmann further states that, this third thesis is based on two assumptions.

The first assumption, which is also his fourth thesis, is that democracy requires taking into account all relevant interests and balance them in order to achieve a reasonably agreeable solution. ${ }^{178}$ In a democratic process, no relevant interest is to be disregarded. All contradictory interests could not be addressed, and thus a choice would be made by weighing those conflicting interests and decisions are made by majority. ${ }^{179}$ It is stated that, often, fundamental rights are provided for in the constitution and they are normative restrictions to the legislative power of the state.

There is always weighing of the conflicting principles; however, those standards of restriction come in different forms based on the nature of the right that is implicated. Avila enumerates them as proportionality, reasonableness and prohibition of excess. ${ }^{180}$ The US Supreme Court, on the other hand, developed three level of scrutiny -strict scrutiny, intermediate scrutiny, and rational basis scrutiny. ${ }^{181}$ Thus, the second assumption of Sieckmann's third thesis, which is also his fifth thesis, is that, "fundamental rights are most important interests [...] that legislation must necessarily take into account". ${ }^{182}$

He further asserts that the connection with the demands of rationality of legislation follows from two further assumptions - proportionality and normative decision. Thus, in perfect conformity with the principle theory of rights, his sixth thesis is that "the balancing of fundamental rights or other constitutional principles must follow the principle of proportionality". ${ }^{183}$ As stated earlier, when two principles collide, we resolve the conflict by weighing the relative

\footnotetext{
${ }^{177}$ Sieckmann (2013), supra note 153, at 109.

${ }^{178}$ Ibid.

${ }^{179}$ Elsewhere, Sieckmann argues for balancing and proportionality. See J Sieckmann (2016), "Rational Lawmaking, Proportionality and Balancing" in K Meßerschmidt and AD Oliver-Lalana (eds), Rational Lawmaking under Review: Legisprudence According to the German Federal Constitutional Court (Springer,).

${ }^{180}$ Avila, supra note 117 , at 92, 95, 101, 105, 112.

${ }^{181}$ Gardbaum, supra note 161, at 391. Husak suggests that before the adoption of a criminal statute, the US Congress should see to it that it meets 'intermediate scrutiny' standard. Husak, supra note 135, at $210-212$.

${ }^{182}$ Sieckmann (2013), supra note 153, at 109.

${ }^{183}$ Ibid.
} 
weight of the conflicting principles. Proportionality is used to assess the counterweight between the means and the end. Sieckmann's seventh thesis is that "the principle of proportionality presents [...] requirements of rationality respecting normative decision or judgments". ${ }^{184}$ Stated otherwise, balancing and proportionality are methods of rational decision making. And the legislature makes such evaluation not once, but, continuously. ${ }^{185}$ However, as legislative balancing of proportionality and review of public policy are inadequate for the effective enforcement of the bill of rights, resort to the adjudicative process is natural. $^{186}$

\section{The Practice of Criminalisation in Ethiopia}

The criminal law is found scattered in various legislation. The 2004 Criminal Code is a continental criminal code that is said to have contained criminal matters comprehensively. ${ }^{187}$ When the 1957 Penal Code was revised into the 2004 Criminal Code, it is designed to include all possible criminal matters and in not few cases, with increased punishment. This is assisted by a sentencing guideline that 'help' increase the sentence from what is provided for in the Criminal Code. ${ }^{188}$

\subsection{Other laws that contain penal provisions}

Several other laws contain penal provisions, either modifying the provisions of the Criminal Code, or introducing new penal provisions. We can use different categories for convenience. The first category includes special penal legislation, such as, the Vagrancy Control Proclamation No 384/2004, Corruption Crimes

${ }^{184}$ Ibid.

${ }^{185}$ Generally, see, Wintgens (2002), supra note 176; AM Arenas (2016), "Theoretical and Procedural Aspects of the Evaluation of Public Policies" in AN Martin and MM de Morales Romero (eds), Towards a Rational Legislative Evaluation in Criminal Law (Springer,) at $3 \mathrm{ff}$.

${ }^{186}$ AD Oliver-Lalana (2016), "Due Post-Legislative Process? On the Lawmakers' Constitutional Duties of Monitoring and Revision" in K Meßerschmidt and AD OliverLalana (eds), supra note 179, at 257.

${ }^{187}$ One of the reasons for the adoption of the Code was the desire "to adopt a comprehensive code by assembling the various criminal provisions published in the Negarit Gazeta in a disintegrated manner." Preface of the Criminal Code, para 4.

${ }^{188}$ Art 88(4) of the Criminal Code authorises the Federal Supreme Court to adopt sentencing manual "in order to ensure the correctness and uniformity of sentencing". The manual increases the sentence that is already fixed in the Criminal Code. Simeneh Kiros Assefa and Cherinet Hordofa Wetere (2008 E.C.), Criminal Investigation, Prosecution and Litigation Manual (in Amharic), United Printers; Nuru Seid (2016), 'Problems of the Revised Sentencing Guideline No 2/2006 E.C.' (in Amharic), 5 Ethiopian Bar Review 119 , at 133 . 
Proclamation No 881/2015, Anti-Terrorism Proclamation No 652/2009, Prevention and Suppression of Money Laundering and Financing of Terrorism Proclamation No 657/2009, Computer Crimes Proclamation No 958/2016 and Prevention and Suppression of Trafficking in Persons and Smuggling of Migrants Proclamation No 909/2015.

The second category includes administrative regulatory legislation adopted by the House of Peoples' Representatives in Proclamations containing penal provisions. They are diverse and need to be put under different sub-categories:

(a) legislation governing financial business, such as, Banking Business Proclamation No 592/2008 and Micro-Financing Business Proclamation No 626/2009;

(b) legislation governing commercial activities, such as, Commercial Registration and Business License Proclamation No 980/2016, Trade Competition and Consumers Protection Proclamation No 813/2013; Ethiopian Commodity Exchange Proclamation No 550/2007; and Coffee Quality Control and Marketing Proclamations No 602/2008;

(c) legislation governing expression and the media, such as, Broadcasting Services Proclamation No 533/2007, Protection of the Media and Access to Information Proclamation No 590/2008;

(d) tax laws, such as, Value Added Tax Proclamation No 285/2002, Income Tax Proclamation 286/2002, Excise Tax Proclamation No 307/2002, Turn Over Tax Proclamation No 308/2002, Tax Administration Proclamation No 983/2016;

(e) legislation governing public property and finance, such as, Federal Government of Ethiopia Financial Administration Proclamation No 648/2009, and Ethiopian Federal Government Procurement and Property Administration Proclamation No 649/2009; (e) various legislation, such as, transport legislation, environmental regulation legislation, coffee quality control. ${ }^{189}$

The criminal law making power of the House of Peoples' Representatives emanates from Art 55(5) of FDRE Constitution on the basis of which the Criminal Code is adopted. However, there are several penal legislation or legislation containing penal provisions adopted by invoking Art 55(1) of the FDRE Constitution in the preambles of the proclamations. Such laws, for instance, include the Anti-Terrorism Proclamation No 652/2009, Banking Business Proclamation No 592/2008, Revised Anti-Corruption Special Procedure and Rules of Evidence Proclamation No 434/2005, and Prevention

189 The diverse nature of the laws that contain penal provisions may be illustrated by Transport Proclamation No 468/2005; Copyright and Neighbouring Rights Proclamation No 410/2004; Environmental Pollution Control Proclamation No 300/2002; Development, Conservation and Utilisation of Wildlife Proclamation No 541/2007; Biosafety Proclamation No 655/2009; and Census Proclamation No 449/2005. 
and Suppression of Money Laundering and the Financing of Terrorism Proclamation No 657/2009.

\subsection{Subsidiary rules}

Various Council of Ministers Regulations and agency directives include penal provisions which raise a host of issues. The first and most important subject relates to delegation of criminal lawmaking power. For instance, Art 2(1) of the Money Laundering Proclamation No 657/2009, provides for a list of "accountable persons" that are (under Art 17) required to give information regarding their clients and/or report suspicious transactions at the pain of criminal punishment. However, the Financial Intelligence Centre is expressly authorised to modify this list in a newspaper having national circulation (Art 22).

There are also indirect delegations. For instance, Art 58(7) of the Banking Business Proclamation No 592/2008 provides that "[a]ny person who contravenes or obstructs the provisions of this Proclamation or regulations or directives issued to implement this Proclamation shall be punished with a fine up to Birr 10,000 and with an imprisonment up to three years." This shows that the Council of Ministers or National Bank of Ethiopia unduly defines the facts constituting crime.

For instance, the Federal Supreme Court Cassation Bench in ERCA v. Daniel took the Directive adopted by the National Bank of Ethiopia (published in English), as the ground of prohibition and punished the defendant based on the Proclamation. ${ }^{190}$ This raises matters of clarity of the conduct that is prohibited. The Regulations or the Directive is not, usually, adopted having criminal responsibility in mind. However, the court makes use of such directives for the determination of the scope of the criminal law. This borders normative criminalisation and the actual enforcement of the criminal law.

As directives are not published in the official Negarit Gazeta, the other major concern relates to the manner of declaration of the criminal norm. Article 2 of the Criminal Code provides for the principle of legality, which obviously also requires that the criminal law need to be published in the official Negarit Gazeta. ${ }^{191}$ There are also other provisions affirming the modalities of

${ }^{190}$ Ethiopian Revenue and Customs Authority v Daniel Mekonnen (Cassation File No 43781, 21 July 2010/ Hamle 14, 2002 Ethiopian Calendar), Decisions of the Cassation Division of the Federal Supreme Court, Volume 10, pp. 345-349)

${ }^{191}$ Federal Negarit Gazeta Establishment Proclamation No 3/1995, Art 2(1), establishes the official Federal Negarit Gazeta. Art 2(2) also provides that "[a]ll Laws of the Federal Government shall be published in the Negarit Gazeta." FDRE Const., Art 22. The principle of legality is essentially prospective application of the criminal law, which 
publication. Art 343 of the Criminal Code, for instance, provides that " $[\mathrm{w}]$ here a crime is committed in breach of legislation issued by an authorised pubic organ in accordance with the law and duly published in the Federal Negarit Gazeta [...] concerning the control or protection of the fiscal or economic interests of the State, the punishment shall be determined in accordance with the principles in this Code." However, in practice, such requirement is shrugged off and directives are given legal effect. ${ }^{192}$

This shows the practice of blanket criminalisation wherein the criminalised conduct is not clear at all. It also indicates the extent to which the universe of the criminal law is fast expanding; i.e., the scope of conducts is expanding, often the new ones are not justified; ${ }^{193}$ punishments are constantly increased, ${ }^{194}$ criminal rules are adopted by agencies on delegation, and the court is (with regard to interpretation and application of the criminal law) resorting to using 'materials' that are not legal rules published in the official Negarit Gazeta. The lawmaker criminalises conducts far broader than that is necessary and justified under the circumstances. Some of the legal interests could have been better protected by administrative action than by criminal law, such as, tax collection and commercial registration.

Under settings which allow such criminal laws, the lawmaker fails to discharge its constitutional obligation to legislate, and in some instances, it abdicates its obligation by delegating criminal law making power to the executive. Blanket criminal rules violate the principle of legality; and there are criminal provisions that violate the principle of conduct and of personal responsibility by imputing criminal liability to another person, such as, company

otherwise means, it prohibits retroactive application of the criminal law. Simeneh Kiros Assefa (2017), 'Methods and Manners of Interpretation of Criminal Norms' 11 Mizan Law Review 88, 104 - 107.

${ }^{192}$ ERCA v Daniel, supra note 190.

${ }^{193}$ For instance, Commercial Registration Proc No 980/2016, Art 49(4) punishes transferring "business licence to third party by way of sale, lease, donation or in a similar fashion" with fine from Birr 50,000 to Birr 100,000 and rigorous imprisonment from 5 to 10 years. However, if the transfer was made to a foreign national, the punishment would be fine from Birr 200,000 to 300,000 and rigorous imprisonment from 7 to 15 years.

${ }^{194}$ Engaging in ordinary commercial activities without a license is made a criminal conduct in Commercial Registration and Business Licensing Proclamation No 67/1997 as part of the trade regime reform. Thus, a person who engages in commercial activities without having a valid license would be punished with fine equal to double the revenue earned, and with imprisonment from 3 to 5 years (Art 46/1). However, the punishments are significantly increased in Commercial Registration and Business License Proclamation No 686/2010 (Art 60/1). Thus, those conducts were made punishable with rigorous imprisonment from 7 to 15 years, fine from Birr 150,000 to 300,000 and confiscation of production or delivery equipment. This is maintained in Art 49 of the current Commercial Registration and Business License Proclamation No 980/2016. 
managers, and violate the principle of culpability by introducing strict criminal liability. Such presentation of the criminal law gives the impression that the lawmaker is not bound by any rule as long as it adopts a criminal rule. It appears to have given the state a freehand to use the criminal law to achieve any state purpose, which otherwise are not meant to protect legal good.

In the normal course of things, one would expect the legislature would discuss any bill for conformity with the Constitution, its jurisdictional matters and the bill of rights, as well as in order to make a better legislation. ${ }^{195}$ There is no record which shows that such discussions were made on legislation containing penal provisions, either as a penal legislation or administrative provision containing penal provisions,. In fact, the preparatory materials for the administrative legislations containing penal provisions do not indicate the rationale behind the penal provisions. ${ }^{196}$

The lawmaking process appears to be skewed because any administrative agency can draw a bill on which it claims competence and submit it to the Council of Ministers. The bill is then sent to the House of Peoples' Representatives, which refers it to the appropriate Standing Committee. ${ }^{197}$ Often, the Standing Committee recommends for adoption of a bill into law with editorial changes. Once, it is presented to the full House, it appears to be an up or down vote. Owing to the institutional gaps in constitutional litigation and practice, Ethiopia does not seem to have a chance to correct legislative missteps.

${ }^{195}$ The "Brief Explanatory Note on Freedom of the Media and Access to Information Bill", which was later adopted as Proclamation No 590/2008, and which adopted the bill of rights interpretation method. However it is not faithfully complied with.

${ }^{196}$ See for instance, "Minutes of Meeting of the Economic Affairs and Legal Affairs Standing Committees with Resource Persons Regarding the Draft Bill on Value Added Tax 7 November 2001" (in Amharic); "Minutes of the Public Hearing Organised by the House of Peoples' Representatives Commercial Affairs Standing Committee on the Commercial Registration and Business License Draft Bill 5 July 2016" (in Amharic); and "Minutes of Public Hearing Organised by Trade and Industry Affairs Standing Committee on Draft Bills of Competition and Consumer Protection, and Commercial Registration 16 June 2010" (in Amharic).

${ }^{197}$ The rules governing legislation are the Federal Democratic Republic of Ethiopia House of Peoples' Representatives Working Procedure and Members' Code of Conduct (Amendment) Proclamation No 470/2005 and the House of Peoples' Representatives Rules of Procedure and Members' Code of Conduct Regulation No 6/2015. These legislation rules were adopted by virtue of Art 59(2) of the FDRE Constitution. The most important legislative rule governing a broad range of pre-legislative activities is the Council of Ministers Working Directive 1996 (E.C., in Amharic). It governs initiation of bills and adoption procedure before the Council of Ministers, the single most important source of bills. 


\section{Conclusion}

Sovereignty is a supreme power of the state which includes criminalisation. The doctrine of sovereignty and the power of criminalisation are not unlimited. The doctrine of sovereignty has inherent limitation on such power demanding legitimacy of the power and the manner in which such power is exercised. As sovereignty is constituted in and vested on the state by a constitution, the latter also contains restrictions that are both formal and substantive. The substantive restrictions are the bill of rights which are required to be taken as principles. When there is conflict between public policy and a fundamental right, a specific method of interpretation is adopted, in order to determine whether the intended measure is appropriate, necessary and proportional. This is normally adopted in adjudication context; however, taking the final consequences into consideration, the legislator needs to adopt such method into consideration.

The doctrine of sovereignty is vague in the Ethiopian Constitution, and in effect, it is not surprising if one holds reservation regarding the legitimacy of the criminal law. However, the criminal lawmaking power of the HoPR is justified by Art 55(5) of the Constitution, which is not complied with. The criminal law takes different forms and its reach is expanding contrary to almost all principles. This might be the result of gaps in the lawmaking process, including parliamentary debate. There is also the need for examination of the legislative power in light of the issues discussed in the preceding sections of this article. The fact that the criminal lawmaking power of the HoPR appears to be unlimited, along with other factors, give the impression that there is 'unjustified' use of criminal law. 